\title{
Temperature-sensitive DNA Synthesis in a Mutant of Bacillus subtilis
}

\author{
By G. W. BAZILL* AND YVONNE RETIEF \\ Medical Research Council, Radiobiological Research Unit, Harwell, \\ Didcot, Berkshire
}

(Accepted for publication 3 December 1968)

SUMMARY

The properties of a temperature-sensitive mutant of Bacillus subtilis in which DNA synthesis is specifically and reversibly inhibited above $40^{\circ}$ are described. When incubated at $45^{\circ}$ there was no detectable breakdown of DNA in the mutant and the synthesis of deoxynucleoside triphosphates was normal. The temperature-sensitive element affects DNA synthesis in vivo but not in vitro and (unlike an initiator) it appears to be needed for DNA synthesis throughout the replication cycle.

\section{INTRODUCTION}

In the hope that biochemical studies of mutants with abnormal DNA synthesis might reveal new features of the replication mechanism, some temperature-sensitive mutants of Bacillus subtilis were isolated and examined. This report describes the properties of one mutant in which DNA synthesis, but not other macromolecular synthesis, ceases at $45^{\circ}$.

\section{METHODS}

Chemicals. Nucleosides, nucleotides, nucleoside triphosphates and bromodeoxyuridine were from Sigma Chemicals Ltd., London. Tritiated thymidine (methyl-T, ${ }_{5} \mathrm{Ci} / \mathrm{m}$-mole), $\left[{ }^{14} \mathrm{C}\right]$ thymine $58 \mathrm{mCi} / \mathrm{m}$-mole, $\left[{ }^{14} \mathrm{C}\right]$ thymidine $36 \mathrm{mCi} / \mathrm{m}$-mole, $\left[5^{-3} \mathrm{H}\right]$ uridine $3.5 \mathrm{Ci} / \mathrm{m}$-mole, $\left[{ }^{14} \mathrm{C}\right]$ leucine $34 \mathrm{mCi} / \mathrm{m}$-mole and carrier free $\mathrm{H}_{3}{ }^{32} \mathrm{PO}_{4}$ were from the Radiochemical Centre, Amersham, Bucks., England. Schwartz BioResearch Inc., New York, supplied $\left[{ }^{3} \mathrm{H}\right] \mathrm{TTP}, 4 \cdot 8 \mathrm{Ci} / \mathrm{m}$-mole. Amino acids were from British Drug Houses Ltd., chloramphenicol from Allen and Hanbury, London.

Bacteria. Mutant strains of Bacillus subtilis were obtained by courtesy of the

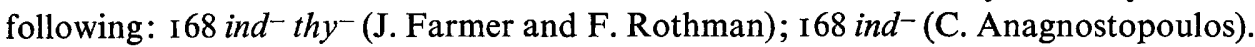

Spores were grown at $30^{\circ}$ on Schaeffer agar plates and were prepared and purified as described by Yoshikawa (1965).

Media. Difco Antibiotic Medium no. 3 (I6 g./1.) was used for routine culture and plating and is referred to throughout as broth. Salts medium was Spizizen minimal medium (Anagnostopoulos \& Spizizen, 196I) supplemented when necessary with thymidine 5 or $10 \mu \mathrm{g} . / \mathrm{ml}$., L-tryptophan $50 \mu \mathrm{g} . / \mathrm{ml}$. and casein hydrolysate (Oxoid) $200 \mu \mathrm{g} . / \mathrm{ml}$.

* Present address: M.R.C. Microbial Genetics Unit, Department of Molecular Biology, The University, West Mains Road, Edinburgh 9. 
For some experiments a rich defined medium (A.S. medium) was used which consisted of minimal salts medium supplemented with amino acids as in the spore germination medium of Donnellan, Nags \& Levinson (1964). It was made as follows: $2 \mathrm{ml}$. concentrated minimal salts medium (Vogel \& Bonner, 1956) plus $5 \mathrm{ml}$. 10\% $(\mathrm{w} / \mathrm{v})$ glucose was diluted to $100 \mathrm{ml}$. with a solution containing L-valine $0.2 \mathrm{~g}$. Larginine $\mathrm{HCl} 0.5 \mathrm{~g}$., L-leucine $\mathrm{I} \cdot 0 \mathrm{~g}$., L-threonine, $0.5 \mathrm{~g}$., L-serine $0.63 \mathrm{~g}$. L-glutamine $4.7 \mathrm{~g}$., L-alanine I.25 g., L-asparagine $\mathrm{I} \cdot 5 \mathrm{~g}$. $/ 1$. The concentrated salts, the glucose and amino acid mixture were autoclaved separately. Thymidine $(5 \mu \mathrm{g} . / \mathrm{ml}$.) and tryptophan $(50 \mu \mathrm{g} . / \mathrm{ml}$.) were added to the medium when required.

For experiments on ${ }^{32} \mathrm{P}$-labelled nucleotide pools, bacteria were grown in $1 \%$ Difco peptone. A sample of the batch of peptone used was analysed for total phosphate after digestion with perchloric acid. The I $\%(\mathrm{w} / \mathrm{v})$ peptone medium contained $0.77 \mu$ mole phosphate per $\mathrm{ml}$. Thymine-requiring strains grew well in this peptone; additional thymine was not needed.

Assays of DNA, RNA and protein synthesis. The incorporation of TCA-insoluble $\left[{ }^{3} \mathrm{H}\right]$ or $\left[{ }^{14} \mathrm{C}\right]$ thymidine, $\left[5^{-3} \mathrm{H}\right]$ uridine and $\left[{ }^{14} \mathrm{C}\right]$ leucine was taken to be a measure of the synthesis of DNA, RNA and protein respectively. Duplicate $0.2 \mathrm{ml}$. samples were taken from the labelled culture at intervals. The samples were frozen immediately in acetone + solid $\mathrm{CO}_{2}$ and stored at $-20^{\circ}$. At a convenient time (generally the following day) they were allowed to melt and $3 \mathrm{ml}$. cold $6 \%(\mathrm{w} / \mathrm{v})$ TCA was added. After standing at $4^{\circ}$ for not less than $20 \mathrm{~min}$. the samples were filtered on $2 \mathrm{~cm}$. Oxoid membrane filters, washed five times with cold TCA, twice with methylated spirit, placed in counting vials and allowed to dry at room temperature. The radioactivity was measured in a Beckman scintillation counter.

Cell extracts for in vitro assays. About I g. (wet weight) of bacteria growing exponentially at $30^{\circ}$ in 21 . of broth was collected by centrifugation. The packed organisms were washed once with $0.02 \mathrm{M}$-phosphate buffer $(\mathrm{pH} 7)$ suspended in $20 \mathrm{ml}$. of the same buffer and incubated for $\mathrm{I} \mathrm{hr}$. at $30^{\circ}$ with $\mathrm{I} \mathrm{mg}$. lysozyme. The lysate was then centrifuged at $10^{\circ}$ for $\mathrm{I}$ hr at $38,000 \mathrm{~g}$. The supernatant fluid was decanted and frozen in $\mathrm{CO}_{2}+$ acetone and stored at $-20^{\circ}$.

Assay of DNA polymerase in vitro. Cell extract (0. I $\mathrm{ml} .5$ to $8 \mathrm{mg}$. protein $/ \mathrm{ml}$.) was added to $0.9 \mathrm{ml}$. of $0.0 \mathrm{I} \mathrm{M}$-tris $\mathrm{HCl}$ buffer $\left(\mathrm{pH}_{7} \cdot 2\right.$ ) containing $\mathrm{I} \cdot 6 \mu$-mole $\mathrm{Na}$ ATP, $2.5 \mu$-mole $\mathrm{MgSO}_{4}, 85 \mu$ m-mole dAMP, dCMP and dGMP, $7.0 \mu$ m-mole [ $\left.{ }^{3} \mathrm{H}\right] \mathrm{TTP}$ (0.5 Ci/m-mole) and $80 \mu \mathrm{g}$ native Bacillus subtilis DNA, prepared by the method of Marmur (196I) from B. subtilis strain I68 ind.-. Incubation was in stoppered tubes at $30^{\circ}$ or $45^{\circ}$. Samples of $0.025 \mathrm{ml}$. were removed at intervals on to filter-paper discs (Bollum, I959) washed five times with 6\% TCA, twice with methylated spirit, dried and the radioactivity counted.

Analysis of nucleoside triphosphate pool. (1) $\left[{ }^{3} \mathrm{H}\right]$ thymidine triphosphate: cultures of ts $230\left(2 \times 10^{7}\right.$ cells $/ \mathrm{ml}$.) in $10 \mathrm{ml}$. broth were labelled for $10 \mathrm{~min}$. at $30^{\circ}$ or $45^{\circ}$ with $\left[{ }^{3} \mathrm{H}\right]$ thymidine $\left(2 \mu \mathrm{Ci} / \mathrm{ml}\right.$.) after growth at $30^{\circ}$ or after one hr at $45^{\circ}$. The organisms were filtered on $2 \mathrm{~cm}$. membrane filters and washed rapidly with $0.5 \mathrm{ml}$. broth to remove extracellular $\left[{ }^{3} \mathrm{H}\right]$ thymidine. The filters were covered with $0.8 \mathrm{ml}$. cold $6 \%$ (w/v) TCA and the organisms were suspended by stirring with a fine glass rod. After $30 \mathrm{~min}$. at $4^{\circ}$, the suspension was centrifuged and the supernatant fluid extracted six times with about $3 \mathrm{ml}$. diethyl ether to remove TCA. Remaining acidity was neutralized with one drop of 0.1 M-trisodium citrate solution. Carrier TMP and TTP 
( $0.5 \mathrm{mg}$. of each) was added and $0.1 \mathrm{ml}$. of this solution was applied to paper strips (Whatman $3 \mathrm{MM}$ ) for electrophoresis according to Smith (I955) in 0.05 M-citrate

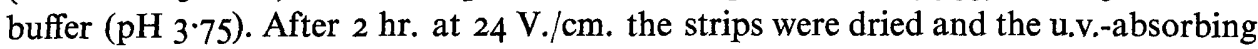
regions marked. The strips were then cut into $0.5 \mathrm{~cm}$. sections and their radioactivities determined.

(2) ${ }^{32} \mathrm{P}$ nucleoside triphosphates: the techniques used were basically those of Randerath \& Randerath (1964) and Neuhard \& Munch-Petersen (1966). Two volumes of $10 \mathrm{ml}$. were taken from an exponentially growing culture of ts 230 in I \% peptone at a density of $3 \times 10^{7}$ bacteria $/ \mathrm{ml}$. One volume was incubated at $30^{\circ}$ and the other at $45^{\circ}$ for $30 \mathrm{~min}$., then $0.1 \mathrm{mC} \mathrm{H}_{3}{ }^{32} \mathrm{PO}_{4}$ (carrier-free) was added to each culture, to give a final specific activity of $\mathrm{I} 3 \mu \mathrm{Ci} / \mu$-mole phosphate. Incubation was continued at $30^{\circ}$ and $45^{\circ}$ for $15 \mathrm{~min}$., then the organisms were filtered on $2 \mathrm{~cm}$. membrane filters (Millipore, $0.45 \mu$ ) and washed rapidly with I $\mathrm{ml}$. of peptone to remove extracellular ${ }^{32} \mathrm{PO}_{4}$. The membrane filters were placed in flat-bottomed tubes containing $\mathrm{I} \mathrm{ml}$. distilled water, frozen immediately in a $\mathrm{CO}_{2}+$ acetone bath and stored at $-40^{\circ}$.

To extract the ${ }^{32} \mathrm{P}$-labelled nucleotides, $3 \mathrm{ml}$. cold $6 \%(\mathrm{w} / \mathrm{v}) \mathrm{TCA}$ was added to the frozen filtered bacteria, followed by $0.0 \mathrm{I} \mathrm{ml}$. of a mixture containing $3 \mu$-mole $/ \mathrm{ml}$. of ATP, UTP, GTP, CTP, dATP, TTP, dGTP, dCTP. Then 0.0I ml. M-potassium phosphate buffer, $\mathrm{pH} 7 \cdot 0$, was added, the mixture was allowed to thaw and kept at $4^{\circ}$ for $20 \mathrm{~min}$. before it was passed through a millipore filter (pore size $0.45 \mu$ ) and the filtrate was extracted six times with $3 \mathrm{ml}$. diethyl ether. The extract was made neutral with $0.05 \mathrm{ml}$. $\mathrm{M}-\mathrm{NH}_{4} \mathrm{OH}$ and incubated for a few minutes with shaking at $45^{\circ}$ to remove traces of ether. It was then freeze-dried. The residue was dissolved in $0.2 \mathrm{ml}$. distilled water and stored at $-40^{\circ}$.

Thin-layer plates $(20 \times 20 \mathrm{~cm}$.) of polyethylene-imine cellulose were prepared according to Randerath \& Randerath (1964). The ${ }^{32} \mathrm{P}$-labelled extracts (0.005 ml.) were spotted on to the plates together with $5 \mu \mathrm{l}$. of a mixture containing $3 \mu$-mole $/ \mathrm{ml}$. of each ribo- and deoxyribo-nucleoside triphosphate. Plates were developed in the solvent system described by Neuhard \& Munch-Petersen (1966): in the first dimension, $\mathrm{M}$-acetic acid $+\mathrm{M}$-lithium chloride: in the second dimension, $3 \mathrm{M}$-ammonium acetate + $5 \%(\mathrm{w} / \mathrm{v})$ boric acid, the $\mathrm{pH}$ value of the mixture being adjusted to 6.5 with ammonia. After development in the first solvent the plates were dried in a current of cold air and washed for I 5 min. in methanol to remove lithium chloride. After the second development, the plates were dried in warm air and examined by u.v. radiation in a dark room. The position of the u.v. absorbing spots was marked and traced on to thin white paper. The plates were then taped to X-ray film (Kodak 'Kodirex' E.P. $6.5 \times 8 \cdot 5$ ) and exposed for $24 \mathrm{hr}$. Sometimes a longer exposure was needed. If the autoradiograph was satisfactory, the spots previously located by u.v. absorption were excised from the thin-layer plate and their radioactivity counted. The excision was done with a scalpel, after first moistening the spot (ringed in pencil) with a drop of amyl alcohol. Correspondence between the carrier (u.v.-absorbing) and radioactive spots was exact.

Pulse labelling of $D N A$. The retention of tritiated thymidine in bacteria pulselabelled at $30^{\circ}$ then shifted to $45^{\circ}$ was measured as follows: a suspension of strain ts 230 growing in $10 \mathrm{ml}$. Spizizen salts medium with thymidine $10 \mu \mathrm{g} . / \mathrm{ml}$. and tryptophan $50 \mu \mathrm{g} . / \mathrm{ml}$. was filtered at a density of $3 \times 10^{7}$ bacteria $/ \mathrm{ml}$. and suspended in $5 \mathrm{ml}$. medium without thymidine. 
After $3 \mathrm{~min}$. aeration at $30^{\circ}$, Io $\mu \mathrm{Ci}$ thymidine (I $8.6 \mathrm{Ci} / \mathrm{m}$-mole) were added and aeration continued for $2 \mathrm{~min}$. The bacteria were then collected on a membrane filter, washed and suspended in $16 \mathrm{ml}$. salts medium. The suspension was divided into four and incubated with and without thymidine $\left(50 \mu \mathrm{g} . / \mathrm{ml}\right.$.) at $30^{\circ}$ and $45^{\circ}$. Samples of $0.2 \mathrm{ml}$. were taken at intervals and the TCA-soluble radioactivity determined.

Isolation of temperature sensitive mutants. Bacillus subtilis ind ${ }^{-}$thy ${ }^{-}$, grown to a density of $10^{7}$ bacteria $/ \mathrm{ml}$. in $100 \mathrm{ml}$. salts medium, was treated for $2 \mathrm{hr}$ at room temperature with $N$-nitro- $N^{1}$-nitroso-guanidine $20 \mu \mathrm{g}$. $/ \mathrm{ml}$. A plate count at this stage showed approximately I0\% survival. The mutagen was removed by membrane filtration and the bacteria were suspended in broth and kept at $4^{\circ}$ overnight. Next morning the culture was revived in broth at $22^{\circ}$, then transferred to $\mathrm{I} 0 \mathrm{ml}$. salts medium with $50 \mu \mathrm{g}$./ $\mathrm{ml}$. trytophan, $0.05 \%(\mathrm{w} / \mathrm{v})$ casein hydrolysate and $20 \mu \mathrm{g} . / \mathrm{ml}$. bromodeoxyuridine. It was then incubated for $\mathrm{I} \frac{1}{2} \mathrm{hr}$ at $45^{\circ}$ (many cells lysed at this stage). The remaining bacteria were collected on a membrane filter, suspended in $10 \mathrm{ml}$. broth and aerated overnight at $4^{\circ}$. Suitable dilutions were plated to determine the viable count, which was $10^{5}$ bacteria $/ \mathrm{ml}$. Seventy-five broth plates were spread, to give about 70 colonies per plate. After 2 days at $22^{\circ}$, replica plates were made ( 75 plates at $45^{\circ}, 75$ at $22^{\circ}$ ) and colonies growing at $22^{\circ}$ but not at $45^{\circ}$ were picked, streaked, then tested again for temperature sensitivity. Of 5000 colonies examined, twenty proved to be temperature sensitive mutants. Six of these showed restricted DNA synthesis at $45^{\circ}$. The most marked effect was in the strain numbered ts 230 and this was chosen for detailed study.

\section{RESULTS}

Temperature dependence of DNA synthesis. Figure I shows the uptake of $\left[{ }^{3} \mathrm{H}\right]$ thymidine at $37^{\circ}, 45^{\circ}$ and $49^{\circ}$ by the temperature sensitive mutant (a) and the parent strain (b). The bacteria were prelabelled before the temperature shift by growth for more than ten generations in $\left[{ }^{3} \mathrm{H}\right]$ thymidine-A.S. medium.

$R N A$ and protein synthesis. The uptake of $\left[{ }^{14} \mathrm{C}\right]$ leucine $/\left[{ }^{3} \mathrm{H}\right]$ thymidine (Fig. 2) and $\left[5^{-3} \mathrm{H}\right]$ uridine $/\left[{ }^{14} \mathrm{C}\right]$ thymine (Fig. 3) was followed in simultaneous labelling experiments. RNA and protein synthesis continued in the absence of DNA synthesis for about $2 \mathrm{hr}$ after the temperature was raised to $45^{\circ}$. In agreement with this observation, bacterial mass, as judged by turbidity, increased about sixfold during this time.

Morphology, viability and cell division. No unusual change in morphology was seen during the first $30 \mathrm{~min}$. after raising the temperature of a log.-phase broth culture to $45^{\circ}$. Between $30 \mathrm{~min}$. and I hr the bacteria began to lose motility and to grow in long chains, each organism becoming elongated. After $2 \mathrm{hr}$ they had a contorted appearance and swollen regions could be seen, generally at one end of a bacterium but occasionally at both ends, or in the middle. On further incubation ( 3 to $5 \mathrm{hr}$ ) lysis occurred.

Although the total count increased eightfold during incubation at $45^{\circ}$ in broth (Fig. 4) the viable count started to decrease after about half an hour (Fig. 5). In minimal salts medium the behaviour of the mutant was similar to that in broth, but there was less division, elongation and swelling.

Although there was rapid death of vegetative organisms at $45^{\circ}$, there was no loss of viability of ts 230 spores when kept at $45^{\circ}$ in distilled water for $3 \mathrm{hr}$.

The utilization of exogenous thymidine. The contorted filaments formed by ts 230 

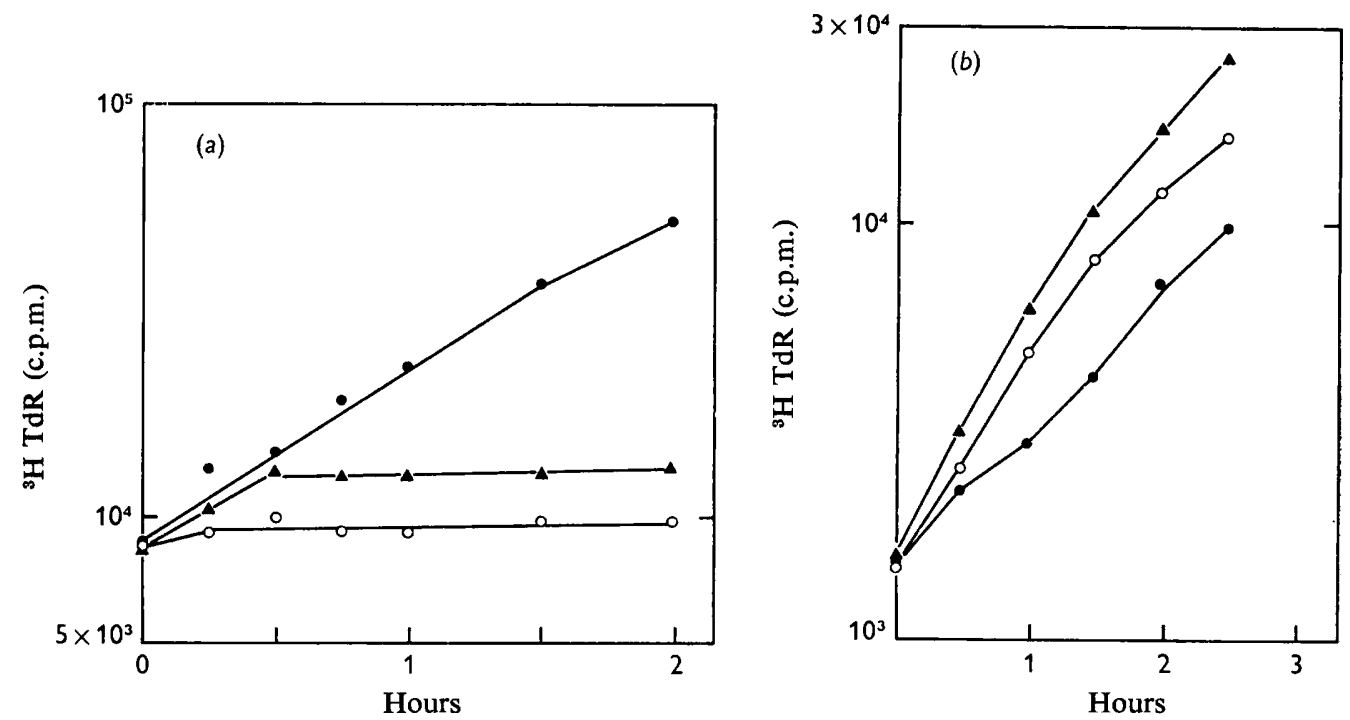

Fig. I. DNA synthesis in ts $230(a)$ and $\mathrm{I}^{6} 6$ ind $^{-}$thy $^{-}(b)$. Log.-phase bacteria growing in A.S. medium at $30^{\circ}$ were diluted and transferred to $37^{\circ}, 45^{\circ}$ or $49^{\circ}$ when the density was $5 \times 10^{6}$ bacteria $/ \mathrm{ml} .37^{\circ}, \bullet \bullet ; 45^{\circ}, \Delta \Delta ; 49^{\circ}, \bigcirc \circ$.

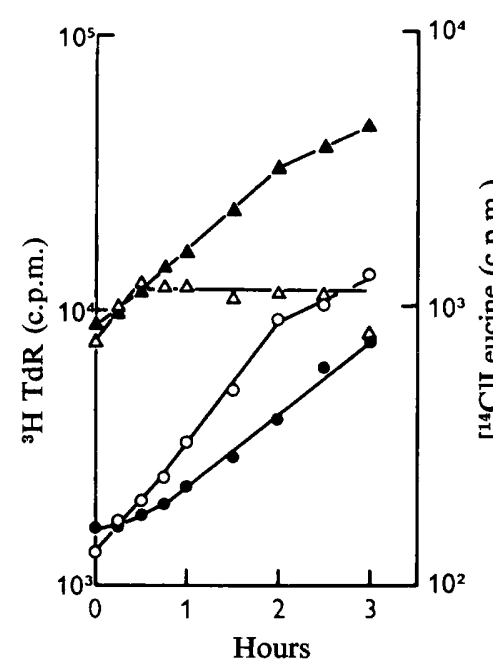

Fig. 2

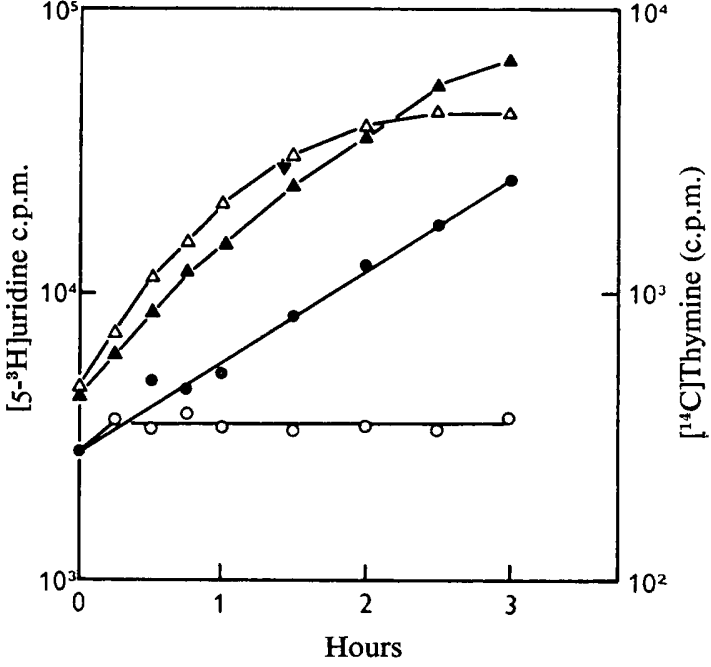

Fig. 3

Fig. 2. Protein and DNA synthesis in ts 230 . Cultures prelabelled by growth for many generations in A.S. medium containing $\left[{ }^{14} \mathrm{C}\right]$ leucine and $\left[{ }^{3} \mathrm{H}\right]$ thymidine were transferred from $30^{\circ}$ to $45^{\circ}$ and the simultaneous uptake of leucine and thymidine was measured. The medium contained $0 \cdot \mathrm{I} \mu \mathrm{Ci} / \mathrm{ml}$. $\left[{ }^{14} \mathrm{C}\right]$ leucine and $\mathrm{I} \cdot 0 \mu \mathrm{Ci} / \mathrm{ml}$. $\left[{ }^{3} \mathrm{H}\right]$ thymidine with $5 \mu \mathrm{g} . / \mathrm{ml}$. carrier thymidine. Bacterial density at temperature shift $5 \times 10^{6} / \mathrm{ml}$. $\left[{ }^{14} \mathrm{C}\right]$ Leucine $32^{\circ}, 0$; $\left[{ }^{14} \mathrm{Cl}-\right.$ leucine $45^{\circ}, O O ;\left[{ }^{3} \mathrm{H}\right] \mathrm{TdR} 32^{\circ}, \Delta \Delta ;\left[{ }^{3} \mathrm{H}\right] \mathrm{TdR} 45^{\circ}, \Delta \Delta$.

Fig. 3. RNA and DNA synthesis in ts 230. Bacteria grown for many generations in A.S. medium containing $\left[5^{-3} \mathrm{H}\right]$ uridine and $\left[{ }^{14} \mathrm{C}\right]$ thymine were shifted from $30^{\circ}$ to $45^{\circ}$ and the subsequent uptake of ${ }^{3} \mathrm{H}$ and ${ }^{14} \mathrm{C}$ measured. The medium contained $0^{\cdot} \mathrm{I} \mu \mathrm{Ci} / \mathrm{ml}$. $\left[{ }^{14} \mathrm{C}\right]$ thymine plus $5 \mu \mathrm{g} . / \mathrm{ml}$. carrier thymine and $\mathrm{I} \cdot 0 \mu \mathrm{Ci} / \mathrm{ml}$. $\left[5^{-3} \mathrm{H}\right]$ uridine. Bacterial density at temperature shift was $5 \times 10^{8} / \mathrm{ml}$. $\left[{ }^{14} \mathrm{C}\right]$ Thymine $30^{\circ}, 0 ;\left[{ }^{14} \mathrm{C}\right]$ thymine $45^{\circ}, \mathrm{O}$; $\left[5^{-3} \mathrm{H}\right]$ uridine $30^{\circ}, \boldsymbol{\Delta} \boldsymbol{\Delta}$; $\left[5^{3} \mathrm{H}\right]$ uridine $45^{\circ}, \triangle \triangle$. 
at $45^{\circ}$ appeared to be similar to those produced by the parent strain of Bacillus subtilis when incubated in a rich but thymineless medium (e.g. spore germination medium, Donnellan et al. (1964)). This suggested that the temperature sensitive lesion in ts 230 might be one which caused failure either to take up thymidine or to convert it to thymidine triphosphate. To test this possibility, ts 230 was grown in broth for $\mathrm{I} \mathrm{hr}$ at $45^{\circ}$, then tritiated thymidine $(2 \mu \mathrm{c} / \mathrm{ml}$.) was added for Io min. The bacteria were rapidly collected on membrane filters and the TCA-soluble extract was examined

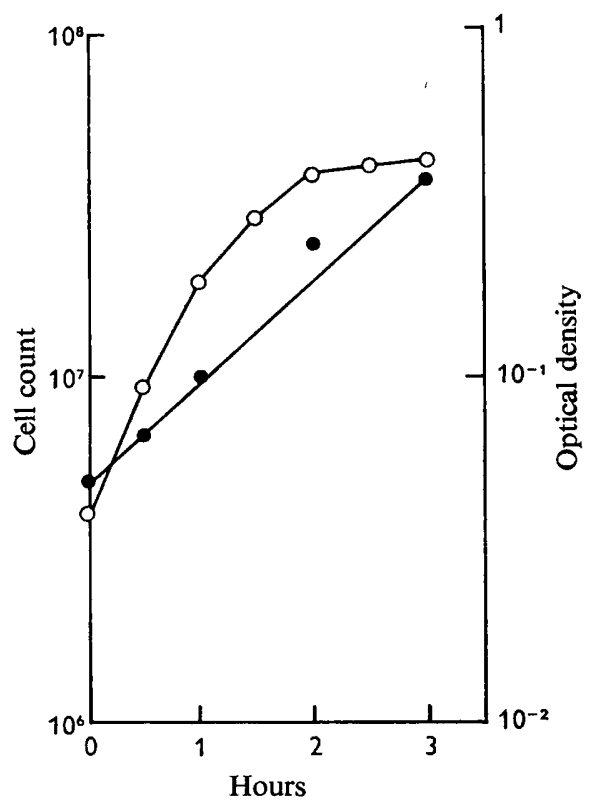

Fig. 4

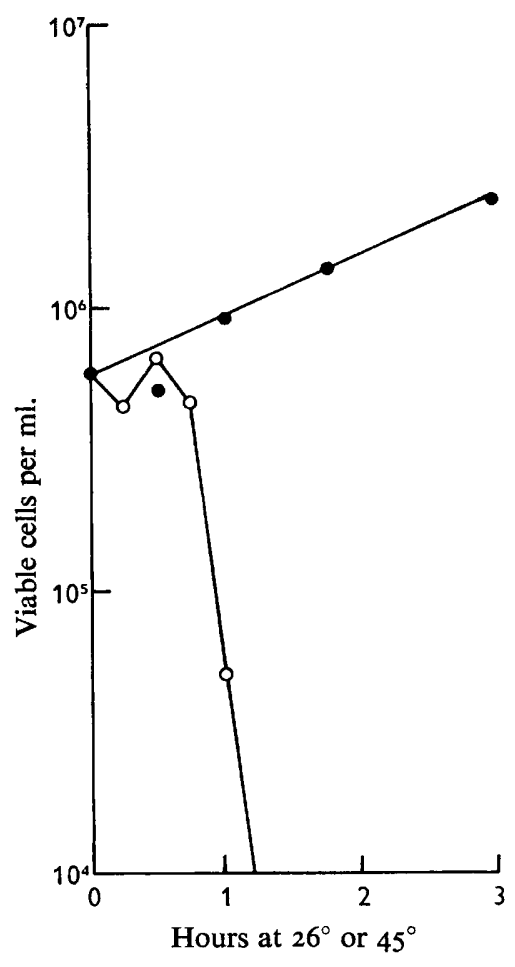

Fig. 5

Fig. 4. Increase of bacterial number and turbidity of ts 230 incubated in broth at $45^{\circ}$. Samples were removed at intervals, shaken with glass beads to disperse aggregates and counted in a Petroff Hauser chamber. Optical density $660 \mathrm{~m} \mu$, $\bigcirc \bigcirc$; bacterial count,

Fig. 5. Survival of ts 230 incubated in broth at $45^{\circ}$. Suitable dilutions were made and $0.1 \mathrm{ml}$. of cultures incubated at $26^{\circ}$ and $45^{\circ}$ were spread on broth plates. Colonies were counted after 2 days at room temperature. Viability at $26^{\circ}$, o viability at $45^{\circ}, 0 \bigcirc$.

by paper electrophoresis to check for the conversion of $\left[{ }^{3} \mathrm{H}\right]$ thymidine to $\left[{ }^{3} \mathrm{H}\right]$ thymidine triphosphate. About $70 \%$ of the radioactivity on the strip was located in the TTP band (Fig. 6).

Synthesis of nucleoside triphosphates. Cultures of ts 230 and the non-temperature-

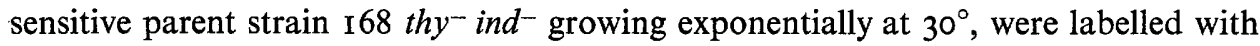
${ }^{32} \mathrm{P}$ as follows: $(a)$ ts 230 at $30^{\circ}$, shifted to $45^{\circ}$ for 30 min., labelled with $\mathrm{H}_{3}{ }^{32} \mathrm{PO}_{4}$ for I5 min. (b) ts 230 at $30^{\circ}$ labelled with $\mathrm{H}_{3}{ }^{32} \mathrm{PO}_{4}$ for $\mathrm{I} 5 \mathrm{~min}$. at $30^{\circ},(\mathrm{c}) \mathrm{I} 68$ thy- ind ${ }^{-}$at $30^{\circ}$ shifted to $45^{\circ}$ for $30 \mathrm{~min}$., labelled with $\mathrm{H}_{3}{ }^{32} \mathrm{PO}_{4}$ for $\mathrm{I} 5 \mathrm{~min}$. at $45^{\circ}$. After labelling, the bacteria were rapidly collected on membrane filters. Acid-soluble extracts were 
prepared and analysed by thin-layer chromatography (see Methods). The radioactive regions located on the chromatographs by autoradiography corresponded exactly to the u.v.-absorbing regions of the carrier (non-radioactive) nucleoside triphosphates. The distribution of radioactivity among the triphosphates is given in Table 1 .

It is evident that the pool of nucleoside triphosphates in the mutant held at $45^{\circ}$ did not differ significantly from that of the controls (the wild-type at $45^{\circ}$ or the mutant at $30^{\circ}$ ). None of the nucleoside triphosphates present in the controls was absent from the $45^{\circ}$ extract; and there were no additional spots, indicative of abnormal nucleotides, on the $45^{\circ}$ autoradiograph.

Table I. Distribution of radioactivity on chromatograms of nucleoside triphosphates in extracts of ts 230 (c.p.m. ${ }^{32} \mathrm{P}$ ).

\begin{tabular}{|c|c|c|c|c|c|c|c|c|}
\hline & ATP & UTP & GTP & CTP & dATP & TTP & dGTP & $\mathrm{dCTP}$ \\
\hline s & 8477 & 6504 & 3656 & 2764 & 673 & 537 & 379 & 878 \\
\hline s 2 & I503I & 5086 & 2370 & 5758 & 1247 & $88 I$ & 702 & 726 \\
\hline$y=3$ & 10436 & 3256 & 1778 & 1370 & 427 & II 46 & 439 & 480 \\
\hline 68 ind $^{-}$thy -2 & I 3455 & 9068 & 2597 & 1815 & 1360 & 1247 & 807 & 571 \\
\hline
\end{tabular}

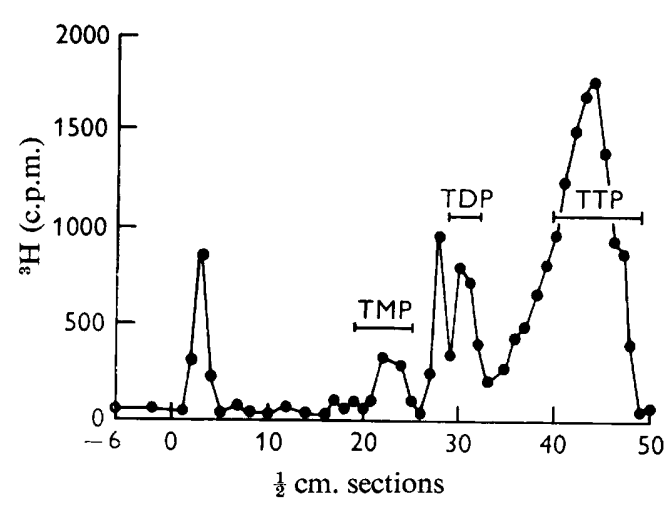

Fig. 6

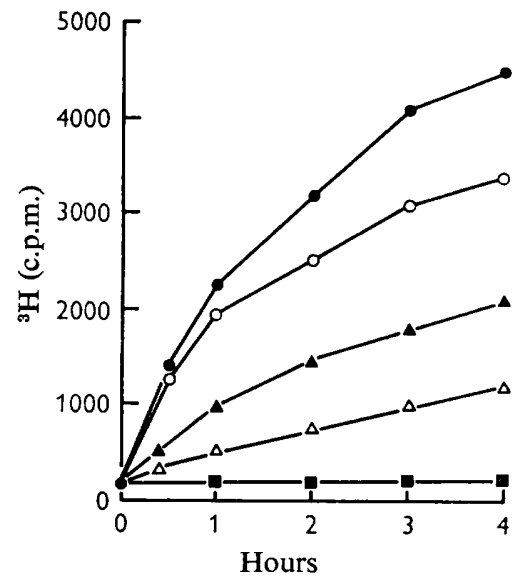

Fig. 7

Fig. 6. Conversion of $\left[{ }^{3} \mathrm{H}\right]$ thymidine to TMP, TDP, and TTP by ts 230 . Bacteria were incubated $\mathrm{I} \mathrm{hr}$ at $45^{\circ}$ then labelled for Io min. at $45^{\circ}$ with $\left[{ }^{3} \mathrm{H}\right]$ thymidine. Distribution of the radioactivity on an electrophoretogram of the TCA-soluble extract is shown. Lines $(-1)$ show the position of u.v. absorbing bands of non-radioactive TMP, TDP and TTP added to the extract.

Fig. 7. DNA polymerase and deoxynucleotide kinase activity in extracts of ts 230 and I 68 ind ${ }^{-}$thy $^{-}$. The reaction mixtures contained $560 \mu \mathrm{g}$. $/ \mathrm{ml}$. ts 230 protein or $825 \mu \mathrm{g}$. $/ \mathrm{ml}$. I 68 ind $^{-}$ thy ${ }^{-}$protein, $7 \mu \mathrm{m}$-mole/ml. ${ }^{3} \mathrm{HTTP}(82,000$ c.p.m. $/ \mu \mathrm{m}$-mole) and other components as given in Methods. The ordinate shows the TCA-soluble radioactivity of $0.025 \mathrm{ml}$. samples. ts 230 extract incubated at $30^{\circ}, \triangle \triangle$; ts 230 extract incubated at $45^{\circ}, \bigcirc \bigcirc ; 168$ ind $^{-}$thy $^{-}$ extract incubated at $30^{\circ}, \Delta \Delta ; 168$ ind $^{-}$thy ${ }^{-}$extract incubated at $45^{\circ}, \bullet$; 168 ind $^{-}$thy $^{-}$ extract incubated at $45^{\circ}$; no ATP,

DNA polymerase tested in vitro. Figure 7 shows the incorporation of $\left[{ }^{3} \mathrm{H}\right] \mathrm{TTP}$ into DNA when cell-free extracts of ts 230 and of the parent strain were supplied with $\left[{ }^{3} \mathrm{H}\right]$ TTP plus deoxynucleotides and ATP. The DNA polymerase was not inactivated by prolonged incubation at $45^{\circ}$. Similar results (not shown) were obtained when the 
enzymes were extracted from organisms which had already been incubated for $\mathrm{I} \mathrm{hr}$ at $45^{\circ}$.

Stability of ts 230 DNA at $45^{\circ}$. No loss of TCA-soluble label was observed either from generally labelled or pulse-labelled organisms: samples of $2.5 \times 10^{6}$ bacteria labelled throughout their DNA remained at $5590 \pm \mathrm{I} 30$ c.p.m. over I $80 \mathrm{~min}$. at $45^{\circ}$. Bacteria pulse-labelled with tritiated thymidine of high specific activity (see Methods) also retained their TCA-insoluble label when incubated at $45^{\circ}$ : samples of $4 \times 10^{5}$ bacteria taken between 15 and 60 min. stayed at $12,435 \pm 330$ c.p.m.; when incubation at $45^{\circ}$ was in medium without thymidine, the count rate stayed at $13,030 \pm 360$ c.p.m.

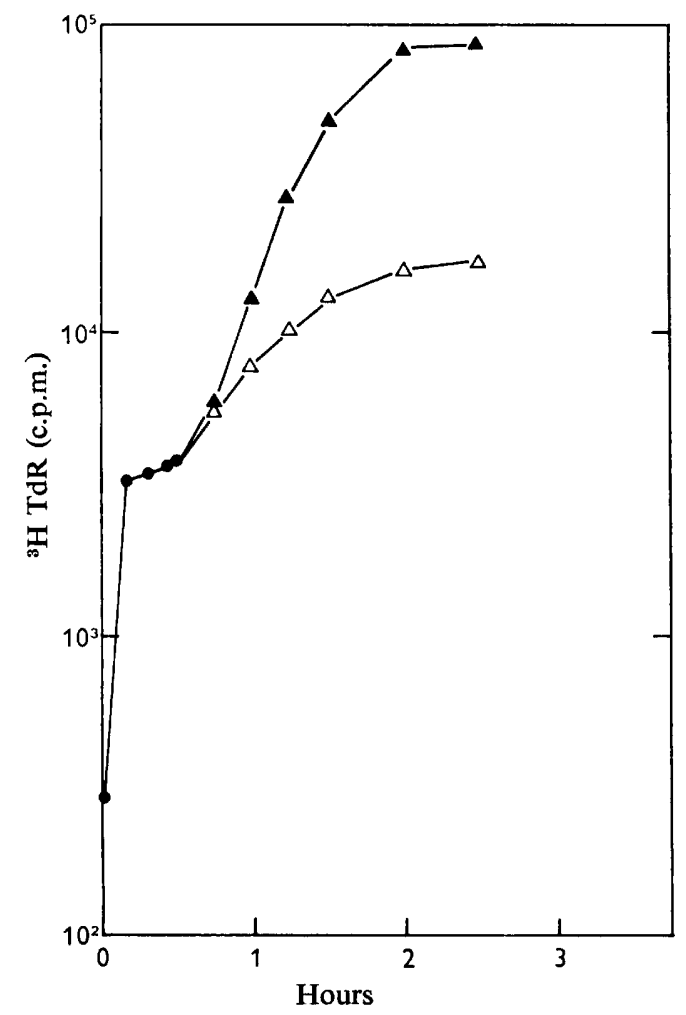

Fig. 8

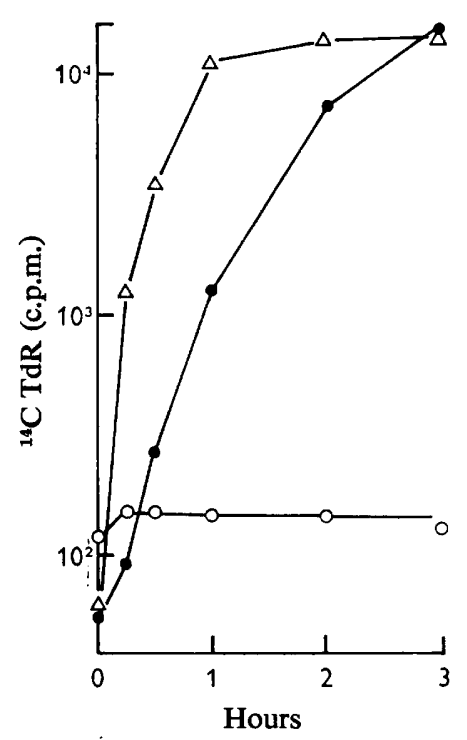

Fig. 9

Fig. 8. Resumption of DNA synthesis at $30^{\circ}$ after inhibition at $45^{\circ}$. Log.-phase ts 230 bacteria at a density of $5 \times 10^{\circ} / \mathrm{ml}$. were incubated in A.S. medium $(5 \mu \mathrm{g} . / \mathrm{ml}$. TdR $)$ with $2 \cdot 0$ $\mu \mathrm{Ci}{ }^{3} \mathrm{H}-\mathrm{TdR} / \mathrm{ml}$. for $30 \mathrm{~min}$. at $45^{\circ}$, then divided into two and transferred to $30^{\circ}$. To one half was added $50 \mu \mathrm{g} . / \mathrm{ml}$. chloramphenicol. No chloramphenicol, $\Delta \Delta$; with chloramphenicol, $\triangle \triangle ; 30$ min. at $45^{\circ}$, $\odot$.

Fig. 9. Resumption of DNA synthesis after thymine starvation at $45^{\circ}$. Log.-phase cultures ( $10 \mathrm{ml}$.) of ts 230 and 168 ind $^{-}$thy $^{-}$were grown in broth at $30^{\circ}$ until the optical density at $600 \mathrm{~m} \mu$ was 0.73 . The bacteria were collected on membrane filters, washed, and suspended at a density of $5 \times 10^{7} / \mathrm{ml}$. in Spizizen salts medium supplemented with $20 \mu \mathrm{g} / \mathrm{ml}$. tryptophan and $0.04 \%$ casein hydrolysate; they were then aerated at $45^{\circ}$ for $15 \mathrm{~min}$. Tubes containing $5 \mathrm{ml}$. broth and $0.1 \mu \mathrm{C} / \mathrm{ml}$. $\left[{ }^{14} \mathrm{C}\right]$ thymidine were inoculated with $0.5 \mathrm{ml}$. of the thymine-starved ts 230 or 168 ind $^{-}$thy suspension and were incubated as follows: (a) 168 ind $^{-}$thy $y^{-}$at $45^{\circ}$, $\triangle \triangle ;(b)$ ts 230 at $45^{\circ}, O \bigcirc ;(c)$ ts $230^{\circ}, \Delta \Delta$. Duplicate $0.25 \mathrm{ml}$. samples were withdrawn at intervals to determine the incorporation of $\left[{ }^{14} \mathrm{C}\right]$ thymidine. 
Reversibility of the block in DNA synthesis. When a log.-phase culture of ts 230 is shifted from $30^{\circ}$ to $45^{\circ} \mathrm{DNA}$ synthesis is stopped within $30 \mathrm{~min}$. If the temperature is then lowered to $30^{\circ}$, DNA synthesis starts again after a short lag. That the resumption of DNA synthesis does not require the synthesis of new protein is shown by the response in the presence of chloramphenicol (Fig. 8).

Thymine starvation at $45^{\circ}$. The inhibition, at temperatures above $40^{\circ}$, of DNA synthesis in ts 230 could be the result of progressive inactivation of an essential enzyme during the first $15 \mathrm{~min}$. of incubation. If so, $15 \mathrm{~min}$. at $45^{\circ}$ in the absence of thymidine would inactivate the enzyme, and subsequent restoration of thymine at $45^{\circ}$ would not produce any further DNA synthesis. On the other hand, if the limited amount of DNA synthesis at $45^{\circ}$ was the result of the organism's inability to initiate new cycles of replication at that temperature, DNA synthesis should be observed after thymine was restored and it should continue until all cycles, interrupted at the time of thymine starvation, were completed.

An experiment to distinguish between these possibilities is shown in Fig. 9. DNA synthesis after thymine starvation for $15 \mathrm{~min}$. at $45^{\circ}$ was zero if thymine was restored at $45^{\circ}$. Control experiments in which thymine was restored to the temperature-sensitive mutant at $30^{\circ}$ or to the parent strain at $45^{\circ}$, showed that the $15 \mathrm{~min}$. period of thymine starvation at $45^{\circ}$ did not itself abolish the capacity for DNA synthesis when thymine was restored.

\section{DISCUSSION}

Bacterial mass and number increase and RNA and protein synthesis continue when ts 230 is incubated at $45^{\circ}$. A non-specific lesion, for example, a change of membrane permeability or a defect in energy metabolism, can therefore be ruled out as a possible cause of the block in DNA synthesis. Of the many possible ways in which a specific block in DNA synthesis could occur, some can be eliminated on the evidence given, while others can be rated as more probable or less probable.

The morphological changes and the loss of viability after a lag period when ts 230 was incubated at $45^{\circ}$ were reminiscent of thymineless death in the parent strain. However, the $t s$ mutant could form TTP from externally supplied thymidine even after I hr at $45^{\circ}$ (Fig. 6). Thin layer chromatography of the acid-soluble extracts of ${ }^{32} \mathrm{P}$-labelled organisms confirmed that the ts mutant was still able to synthesize TTP after $45 \mathrm{~min}$. at $45^{\circ}$, and further showed that the synthesis of dATP, dGTP and dCTP and the ribonucleoside triphosphates was normal at $45^{\circ}$. The temperature-sensitive step in ts 230 is therefore not in the biosynthetic pathways leading to nucleoside triphosphates. The continued activity, at $45^{\circ}$, of the deoxynucleotide kinases in the DNA polymerase assay (Fig. 7) supports this conclusion.

Since the DNA polymerase appeared to function normally at $45^{\circ}$ in vitro, the mutant is not defective in the ability either to produce DNA substrates or to polymerize them. The defect may be due to inability of the organism's DNA to direct the synthesis of new DNA. Such a situation might be caused by double-strand breaks (Cairns \& Davern, 1966) or it might arise if the initiation of new cycles of replication was prevented. These possibilities have been explored in the experiments on the stability of ts 230 DNA at $45^{\circ}$ and on the effects of thymine starvation at $45^{\circ}$.

There was no appreciable release of acid soluble nucleotides from bacteria prelabelled for several generations with tritiated thymidine when they were incubated at 
$45^{\circ}$. Bacteria pulse-labelled at the replicating fork similarly showed no evidence of breakdown of the DNA after a temperature shift. This shows that there was no gross breakdown (e.g. by an uncontrolled deoxyribonuclease) at this temperature. But the production of a small number of single-strand breaks would not have been detected. It is unlikely that double-strand breaks occur in view of the reversibility of the block in DNA synthesis (Fig. 8). There is evidence from studies on the effects of X-rays that Escherichia coli cannot repair double-strand breaks in its DNA (Kaplan, 1966). In Bacillus subtilis, which is not much more resistant to X-irradiation than E. coli, the effect of double-strand breaks would similarly be expected to be irreversible.

If single-strand breaks are the cause of inhibition of DNA synthesis, two possibilities may be considered: (I) single-strand breaks do not occur in the course of normal DNA function, but in ts 230 there is an aberrant enzyme which produces breaks at temperatures above $40^{\circ}$; (2) single-strand breaks do occur and are necessary for normal DNA functions; in ts 230 these breaks are repaired efficiently at $30^{\circ}$ but inefficiently or not at all above $40^{\circ}$.

Neither of these possibilities can be discounted at present and to rule them out completely would require very refined experiments. However, it is by no means certain that the presence of single-strand breaks in DNA would necessarily prevent its replication. Indeed, unless the entire bacterial chromosome rotates when the DNA is replicated (and this seems mechanically difficult) a small number of single-strand breaks would be a prerequisite for replication. One might also expect that if breaks were not repaired they would be extended by exonuclease action. Prolonged exonuclease action should lead to appreciable loss of labelled thymine from the DNA but this did not take place.

The increase of DNA after a temperature shift to $45^{\circ}$ in A.S. medium $(50 \%$ in Fig. I) is close to that expected $(40 \%)$ for the completion of a cycle of replication and failure to initiate a new cycle. But if ts 230 had a temperature-sensitive initiator, replication cycles which could be completed at $45^{\circ}$ should also be completed at $47^{\circ}$ or $49^{\circ}$, the same amount of DNA being synthesized at each temperature. This was not found: the amounts of DNA synthesized decreased with increasing temperature (Fig. I a). Further evidence against the theory that ts 230 is an initiator mutant comes from the experiment illustrated in Fig. 9: the bacteria were held for $15 \mathrm{~min}$. at $45^{\circ}$ in conditions (absence of thymine) where DNA synthesis was impossible. Synthesis of DNA did resume when thymine was restored at $30^{\circ}$, but not when it was restored at $45^{\circ}$. If the temperature-sensitive lesion was one which allowed DNA synthesis to continue to the end of a cycle, those replication cycles already in progress at the time of the temperature shift should have been completed when thymine was restored. But it is clear that they were not completed. Thus the evidence does not support the hypothesis of a temperature-sensitive initiator; rather, it suggests that some element which is continuously needed for DNA synthesis throughout the replication cycle becomes inactivated above $40^{\circ}$ at a rate which increases with temperature.

In the experiments described, all the known components of the DNA replication system have been tested for possible temperature sensitivity, but none of them has proved to be abnormal. The results of the in vitro assay of ts 230 DNA polymerase must be interpreted with caution in view of the evidence of de Waard, Paul \& Lehman (1965), that not all of the ts mutations mapping in the locus for T 4 DNA polymerase 
gave enzymes that were inactive in vitro. Thus the possibility remains that DNA polymerase may be abnormal in ts 230 , present methods of assay being inadequate to detect the abnormality. It now seems very probable that the polymerase responsible for replicating the bacterial chromosome acts at a site on the cell membrane and forms part of a replicative complex through which the DNA duplex passes as it is unwound and copied. Such a complex would include a number of elements, any one of which could be temperature-sensitive in vivo without giving any sign of abnormal sensitivity in vitro. Our present hypothesis is that ts 230 is a representative of one such class of mutants.

One of us (G. B.) is indebted to Drs J. D. Gross and D. Karamata for helpful discussions and for communicating results prior to publication. The very competent assistance of Mrs J. Brogden in the later stages of the work is also gratefully acknowledged.

\section{REFERENCES}

Anagnostopoulos, C. \& Spizizen, J. (I96I). Requirements for transformation in B. subtilis. J. Bact. $8 \mathrm{x}, 74 \mathrm{I}$.

Bollum, F. J. (1959). Thermal conversion of non-priming DNA to primer. J. biol. Chem. 234, 2733.

CAIRNS, J. \& DAVERN, C. I. (I966). Effect of ${ }^{32} \mathrm{P}$ decay upon DNA synthesis by a radiation-sensitive strain of E. coli. J. molec. Biol. 17, 418.

Donnellan, J. E., Nags, E. H. \& Levinson, H. S. (1964). Synthetic media for B. subtilis spores. J. Bact. 87, 332.

KAPLAN, H. S. (1966). DNA-strand scission and loss of viability after X-irradiation of normal and sensitized bacterial cells. Proc. natn. Acad. Sci. U.S.A. 55, 1442.

MARMUR, J. (I961). A procedure for the isolation of DNA from micro-organisms. J. molec. Biol. 3, 208.

Neuhard, J. \& Munch-Petersen, A. (1966). Studies on the acid-soluble nucleotide pool in thyminerequiring mutants of E. coli during thymine starvation. Biochim. biophys. Acta 114, 61.

RANDERATH, K. \& RANDERATH, E. (1964). Ion exchange chromatography of nucleotides on polyethyleneimine cellulose thin layers. J. Chromatog. I6, II I.

SмIтH, J. D. (1955). The electrophoretic separation of nucleic acid components. In The Nucleic Acids. Ed. by E. Chargaff \& J. N. Davidson, vol. I. New York: Academic Press Inc.

Vogel, H. J. \& BONNER, D. M. (1956). Acetylornithinase of E. coli: partial purification and some properties. J. biol. Chem. 218, 97.

De Ward, A., Paul, A. V. \& Lehman, I.R. (1965). The structural gene for DNA polymerase in bacteriophages $\mathrm{T}_{4}$ and $\mathrm{T}$ 5. Proc. natn. Acad. Sci. U.S.A. 54, $124 \mathrm{I}$.

Yoshikawa, H. (1965). DNA synthesis during germination of B. subtilis. Proc. natn. Acad. Sci. U.S.A. $53,1476$. 